\title{
Afro-American, Spanglish, and Something Else: St. Cruzan Naming Patterns
}

\author{
J. L. DILLARD
}

$\mathrm{T}_{\mathrm{H}}$

HE TENDENCY OF ONOMASTIC RESEARCH, especially in the United States, to concentrate on place-names has caused over-emphasis upon the influence of the official or majority culture and under-emphasis of the contributions of the minority, disadvantaged, and "power-"less groups. Such a bias causes the by-passing of acculturation processes in naming. American Indian place-names, for example, are often dealt with; but these are either aboriginal or, in many cases, the result of self-conscious restoration. Important intermediate stages, lacking in exoticism, may be overlooked. Other minority groups, like American blacks for instance, do have clear onomastic patterns - in personal names, ${ }^{1}$ in vehicle names, ${ }^{2}$ and in church names, ${ }^{3}$ if not in place-names. Research outside the United States, especially in the West Indies, has shown that the Afro-American populations which speak varieties of English (particularly Creole and Creole-related varieties) have striking patterns of their own. ${ }^{4}$ Further, some perspective from these patterns may prove useful in understanding patterns in the United States..$^{5}$ Even the Nova Scotian black population

1 For the Afro-American population, the clearest case is that of the day-names. See David DeCamp, "African Day Names in Jamaica," Language 43 (1967), 139-147; Frederic G. Cassidy, Jamaica Talk (1961), 157-8; J. L. Dillard, "The West African Day-Names in Nova-Scotia," Names 19:4 (December, 1971), 257-261.

${ }^{2}$ See J. L. Dillard, Afro-American and Other Vehicle Naming Practices, Institute of Caribbean Studies Special Study No. 1, 1965; "Names of Slogans? Some Problems from the Caribbean, Burundi, and the United States," Caribbean Studies 9, No. 4 (1968), 104 to 110 .

3 James B. Stronks, "Chicago Store-Front Churches: 1964," Names 12:2 (June, 1964), 127-128; R. S. Noreen, "Ghetto Worship: A Study of the Names of Chicago Storefront Churches," Names 13:1 (March, 1965), 19-38; J. L. Dillard, "On the Grammar of AfroAmerican Naming Practices," Names 16:3 (September, 1968), 230-237.

4 See David DeCamp, "Cart Names in Jamaica," Names 8:1 (March, 1960), 15-23; Dillard, "Names or Slogans?" Caribbean Studies, 1968.

5 See Dillard, Caribbean Studies, 1968. In a novel like William Melvin Kelley's BlackJoycean Dunfords Travels Everywheres (Random House, 1968), we find ghetto bar names like

B. Q. 's

HARE'S LATR

The BROWN TURTLE

THE OASIS PALM

JESSE B'S JOYCE CLUB

BROWN'S 
has participated in naming patterns which are usually associated with the West Indies and West Africa. ${ }^{6}$

With recent interest developing in St. Croix, ${ }^{7}$ it may be of some interest to look at the naming patterns of that island in the U.S. Virgin Islands. Populated by black descendants of slaves - complicated by a supercargo population from various European nations and from the

MR. MITEY'S BLESSED DINER
MELVIN'S JAZZMATAZZ GALLERY
SMOKEY'S SMOTHER ROOM
RINEHART'S RESTAURANT
TM'S DREAM ROOM
SONNY R'S BOOM BAR
THE JOHNSON JONES JAIL HOUSE

Although fictional, these names occur in the context of quite self-conscious concern about black culture and identity.

6 Dillard, "The West African Day-Names in Nova Scotia," Names 19:4 (December, 1971), 257-261.

7 Robert J. DiPietro, "Multilingualism in St. Croix," American Speech 43, No. 2 (May, 1968). In spite of the fact that DiPietro's article deals only with "bilingual" and "diglossic" aspects of the co-existence of Cruzan English, (American) Standard English, and Puerto Rican Spanish on the island, there is observable a wide range of St. Cruzan English dialects. The relatively few remaining Danes tend to speak English with a slight but easily perceptible accent; even a French accent or two may be heard on a short stay. U.S. retirees and resort workers, etc., come mainly from the middle class professionals of the East Coast and typically speak something rather close to consensus (Network) Standard. (A surprising number of the room clerks and other such workers are former professionals with college degrees, working at such jobs to supplement retirement income.) So do a great number of the tourists - in fact, an impressionistic survey would place most of them in Westchester County. Puerto Ricans usually speak the hybrid sometimes called "Spanglish"; but some of them, who grew up in St. Croix, speak "Cruzan talk" like the natives, in addition to Spanish.

The Black Cruzans themselves manifest a wide range varying from "Cruzan talk" to Standard English, with varying amounts of interference from the former on the latter. Radio announcers, for example, may be identified as Cruzans by stress patterns (something, airpórt) and by over-careful pronunciation [kángrismån]. Children reading in a service in the Lutheran church retained [dæt] and [tIn] in their formal reading styles, although because of the Biblical text being read no grammatical or lexical effects of Cruzan were observable.

Probably the most extreme "deviations" from Standard English (and from any of the well-known non-standard dialects of the United States and England) can be found in the speech of children. Aida Rouss, "Don't Yank, Taak Yoh Cruzan Taak" (unpublished) hypothesizes that the $d o$-support rule does not apply to Cruzan, and cites sentences like

You know rubber tree?

You see dat stretch de?

You hear me fuss wid anybody?

He wid he madda? (Is he with his mother?)

De nenyam ready? (Is the food ready ?)

In my own talk with children in Christiansted, I was asked "You does got to walk ?" and, when I pretended not to understand after several repetitions, the exasperated "If you 
United States - the island has seen a recent influx of Puerto Ricans, many of them dark-skinned. ${ }^{8}$ As in the other islands, especially those with a heavy tourist trade, the Afro-American naming patterns must co-exist with many other patterns; and they tend to occupy the "private" end of a kind of diglossic naming-practice scale, showing up in the names of small, unimpressive business establishments, in vehicle names, and in the place-names of rural areas.

This is not to say that the Afro-American patterns go underground; they are enough in evidence to be noticed by visitors interested in chronicling the (basically white) social whirl. Horace Sutton, for example, in his Chicago Tribune article "St. Croix: A Danish Delight" (April 18, 1971) reported

Places are called Upper Love ... Lower Love ...

Jealousy ... Dots Folly ... Hannah Rest ...

Judith's Fancy ... Bethlehem ... Slob.

He could have added All For The Better and Profit, among others. Sutton, who called these "balmy" place-names and who also wrote of their "Oz-like" air, hesitantly attributed them to Danish influence. But, since similar names are to be found in West Indian islands with no conceivably great Danish influence, ${ }^{9}$ it is reasonable to conclude that the islander black population deserves the credit for these naming patterns. Sutton, like many another visitor, probably over-generalized from the Danish names of the major towns - Christiansted and Fredericksted - and from the Holger Danske Hotel.

does got to walk ?" which contains a quasi-auxiliary $d o$-form, but hardly in the syntactic function of Standard English. Cruzan children also say things like

"That's your bike. That's what bike you ridín'." Informants have uniformly maintained that the "deep" Creole feature NP de Verb (You de ride)

does not occur in Cruzan, and have readily volunteered the information that NP Verb-ín' (You ridín')

substitutes - thus perhaps indirectly indicating that they are aware of the de forms. Rouss cites "You de de" ["You are there"] which would be an at least marginal use of auxiliary de. This is, of course, a well-known shibboleth; and informant reports may not be trustworthy.

Rouss reports that Cruzan talk is regarded as "bad" (i.e., probably "deeper" Creole) by other islanders. The tendency to stigmatize the speech of other islanders, and to report one's own island as having the "best" (i.e., most nearly Standard, or least Creole) English is, however, a stereotypical West Indian pattern.

8 A few undoubted Africanisms, like nenyam "food," are in Cruzan talk; and Creole structures like the post-posed third person plural marker are also found: Me know me people-dem. Gloria E. Encarnacion's "Cruzan Calypso," a more or less comical use of Cruzan for the tourist trade, features expressions like knackin' daag "in crowds, in great abundance" which remain unexplained and may well be Africanisms.

9 See, for example, Richard and Sally Price, "A Note on Canoe Names in Martinique," Names 14:3 (September, 1966), 160. 
There is, however, another element which is clearly identifiable and easily attributable to the Puerto Ricans who are increasingly migrating to St. Croix. The Puerto Rican naming pattern has been reported, ${ }^{10}$ and some account has been taken of its probable cause: the special confrontation, often a kind of tug of war, between English and Spanish on the island. Although the Puerto Rican language contact situation is actually a rather simple one compared with those of other West Indian islands - and would seem even more absurdly simple to West Africans or to some Asians - Puerto Ricans constantly marvel at their own virtuosity, commemorating it in names of mixed English and Spanish content ("Spanglish"). In many cases, there is reason to doubt that intelligibility for monolingual English speakers and readers is the motivating force for "Spanglish" names; in cases like Yunk, Bird Land's Tabern, Charlie's Melodie's Bar, etc., such devices as the exaggerated use of apostrophes are hyper-Anglicisms which can hardly aid the understanding of outsiders. How many gringos are really enlightened because Cuchilandia, probably on the analogy of Yanquilandia, ${ }^{11}$ contains an English etymon in its third syllable? But Chuchilandia Bar and Restaurant has been transferred to Christiansted. We also find

\section{EL COMETA GROCERY \\ JOSE'S GARDEN \\ EL RUBI BAR \\ PLAZA LECHONERA \\ BAR 2 LUCES}

\author{
JORGE'S PLACE \\ GARCIA'S MARKET \\ BORINQUEN BAR \\ MORALES' GROCERY \\ MIGUEL'S PHOTO STUDIO
}

along with the vehicle name Bad Jose and the Santa Cruz Pharmacy. The term Bar is, of course, the usual one in Puerto Rico; I have never seen Cantina in a name on that island.

Despite the efforts of Independentistas and crusading Hispanists, the home-island Puerto Rican pattern remains one of aggressive acculturation toward the United States, with concomitant insistence upon the Puerto Ricans' use of English to "Americans" (who may include for-

10 J. L. Dillard, "Spanglish Store Names in San Juan, Puerto Rico," Names 12:2 (June, 1964), 98-102, and "Spanglish Store Names Again," Names 14:3 (September, 1966), 178-180. The cliché "The more it changes, the more it's the same thing" is borne out by Puerto Rican "English" names. The Rainbow Grill gets a few more neon lights and becomes New Bronx Casino Club (the clientele of which is entirely Spanish-speaking); Bird Land's Tabern becomes Chick.N.Bar.B.Q. and then just Pizza, but

House

BIRD LAND'S

Restaurant

has reappeared over a door. The Time Square Quick Lunch (Río Piedras) has one new sign which reads Times Square, but the old Time Square still appears elsewhere.

11 The suffix -landia is at least mildly productive. There is, for example, the Gomilandia (from gomas "tires") Refreshment Center, located in the same small sub-building as the stock of tires, in a Texaco station in Santurce. 
eigners from as far away as India, and even an occasional Argentinian) rather than the latter's use of Spanish to Puerto Ricans. ${ }^{12}$ The same feeling of language appropriateness has extended itself to St. Croix, and some younger Cruzans of Puerto Rican ancestry (especially the blacks) are bilingual in St. Cruzan English ${ }^{13}$ and Puerto Rican Spanish. ${ }^{14}$ Despite the general discouragement of Cruzan use of Spanish, there is an occasional attempt (not too well realized) on the part of the English-speaking Cruzans to use Spanish for Puerto Ricans:

\section{DRESSMAKER CUSTURERA [sic]}

The Cruzan tradition itself, besides being apparently manifest in the place-names already referred to, is strikingly evident in vehicle names

\begin{tabular}{ll} 
BABY SHAF & MR. LIGHTNING \\
SAD MOVER & THE DIFFERENT \\
APOLLO II & BUCCANEER \\
CONSIDER ME & \\
LOVE BUG [a Volkswagen, of course] \\
\multicolumn{2}{c}{ Come and See Me }
\end{tabular}

Puerto Ricans in the San Juan area often paint names like Demon El Coqui, and Cobra (with a picture of the snake) on their automobiles, with pictures and in bright letters but smaller and less prominently displayed than the typical names of the English-speaking islands. There is at present no clear evidence linking the Puerto Rican to the Afro-American tradition of naming automobiles. Especially in the case of Demon (a brand name), the Puerto Rican names probably refer to the cars. The Cruzan names, on the other hand, refer primarily to the drivers - like Baby Shaf which is probably best explained as a boast of virility ("the maker of babies"). As DeCamp ${ }^{15}$ has pointed out, the most notable characteristic of this naming tradition is its reflection of the inner states of the owner or driver (Consider $M e$, Sad Mover, The Different), although current events (A pollo II) also get some attention, in Jamaica as in St. Croix. (But the driver in this case is probably claiming reflected glory from the astronauts - or offering to reflect some of his own glory on them! - rather than merely seeking to commemorate an historical event.)

12 J. L. Dillard, "Standard Average Foreign in Puerto Rican Spanish," in E. B. Atwood and A. A. Hill (eds.), Studies in Language, Literature, and Culture of the Middle Ages and Later, Austin, Texas, 1969, pp. 97-108.

13 For these purposes, it is not necessary to resolve the issue of whether this is "perfect" bilingualism - or whether that is possible. These young people are, at the least, capable of fooling all but the most perceptive listener.

14 For some observations on the variable nature of Puerto Rican "folk" Spanish, see J. L. Dillard, "Sobre Algunos Fonemas Puertorriquenas," Nueva Revista de la Filologia Española, XVI (1962), 422-424.

15 "Cart Names in Jamaica," Names 8:1 (March, 1960). 
Cruzan business names are characterized primarily by a certain floridity $:^{16}$

DE [sic] HIVE RESTAURANT AND BAR

WEEKE'S TEN GRAND BAR AND RESTAURANT

DODIE'S SUN AND MOON FASHIONS

HUMMING BIRD LAUNDROMAT

WRINGER ROOM BAR

BARON SPOT CHRISTIANSTED

FALLEN STAR BAR AND RESTAURANT

It seems obvious that the kinds of names noted constitute a separate naming tradition from mainstream American business names (although, obviously, some resemblances can be found). It may be only a posteriori reasoning which separates out a name like The Stone Balloon (a very white, very touristy bar and restaurant). But, in comparison to a mass of other data from West Africa and the West Indies, ${ }^{17}$ West African survival for, especially, the vehicle names ${ }^{18}$ does not seem like an at all extreme hypothesis. The three traditions (West Indian, "Spanglish," and tourist) are basically distinct and each has its own functional domain. Crossing, as in the case of the vehicle name Bad Jose, is more frequent between Cruzan and Spanglish than between either of those two and tourist. (This should be no more surprising than that intermarriage follows the same pattern.) Danish hardly exists at all, except for the older, very official place and street names (and the latter are quite regularly translated into English). The islanders themselves (like the St. Thomas taxi driver who once explained to me that [sent kror] was the French pronunciation of the name of the other island, the Danish pronunciation having been [sent krwa]) are hardly aware that Danish was ever there.

Like that of the continental United States, the Afro-American population of the West Indies has received little attention - onomastic or otherwise - from researchers. What research has been done has been subject to preconceptions which were in fashion at the moment, and to a great degree it has been limited to Jamaica. The promise of comparative studies in the area is, however, bright; and the field is wide. Important contributions to the understanding of black language, cultural, and onomastic patterns in the United States can also result.

University of Puerto Rico

16 Florid names are especially characteristic of storefront churches like Sacred Heart Spiritual Church of Jesus Christ, Inc., in Washington, D.C.

17 See the discussion in Dillard, "Names or Slogans ?" 1968.

18 Although there are no general studies, enough information is available to show that the same practices are to be found in West Africa. John Diggers, Anansi, The Web of Life in Africa, 1962, p. 36, shows Fanti fishing boats with "proverbs and symbols expressing the philosophy of each boat crew" carved on the sides. On the relationship of boat names to other vehicle names, and on the relationship between names, slogans, and "proverbs," see Dillard, "Names or Slogans ?" 1968. 